\title{
Enhanced Electrochemical Performance of Poly(ethylene oxide) Composite Polymer Electrolyte via Incorporating Lithiated Covalent Organic Framework
}

\author{
Yuan $\mathrm{Yao}^{1} \cdot \mathrm{Yu} \mathrm{Cao}^{1} \cdot \mathrm{Gang} \mathrm{Li}^{2} \cdot$ Cheng Liu ${ }^{1} \cdot$ Zhongyi Jiang $^{1,3} \cdot$ Fusheng Pan ${ }^{1,3} \cdot$ Jie Sun $^{1}$
}

Received: 18 May 2021 / Revised: 7 June 2021 / Accepted: 10 June 2021 / Published online: 8 July 2021

(c) The Author(s) 2021

\begin{abstract}
The lithiated covalent organic framework (named $\mathrm{TpPa}-\mathrm{SO}_{3} \mathrm{Li}$ ), which was prepared by a mild chemical lithiation strategy, was introduced in poly(ethylene oxide) (PEO) to produce the composite polymer electrolytes (CPEs). Li-ion can transfer along the $\mathrm{PEO}$ chain or across the layer of $\mathrm{TpPa}-\mathrm{SO}_{3} \mathrm{Li}$ within the nanochannels, resulting in a high Li-ion conductivity of $3.01 \times 10^{-4} \mathrm{~S} / \mathrm{cm}$ at $60{ }^{\circ} \mathrm{C}$. When the CPE with $0.75 \mathrm{wt}$. $\% \mathrm{TpPa}-\mathrm{SO}_{3} \mathrm{Li}$ was used in the $\mathrm{LiFePO}_{4} \| \mathrm{Li}$ solid-state battery, the cell delivered a stable capacity of $125 \mathrm{~mA} \cdot \mathrm{h} / \mathrm{g}$ after 250 cycles at $0.5 \mathrm{C}, 60^{\circ} \mathrm{C}$. In comparison, the cell using the $\mathrm{CPE}$ without $\mathrm{TpPa}-\mathrm{SO}_{3} \mathrm{Li}$ exhibited a capacity of only $118 \mathrm{~mA} \cdot \mathrm{h} / \mathrm{g}$.
\end{abstract}

Keywords Lithiated covalent organic framework $\cdot$ Composite polymer electrolytes $\cdot$ Poly(ethylene oxide) $\cdot$ Solid-state lithium-ion batteries

\section{Introduction}

As the demand for power sources continues to increase, various types of high-performance energy storage devices are developing rapidly [1-3]. Solid electrolytes are the key part of solid-state lithium-ion battery (SSLIB), which is believed as one of the next-generation battery systems with high energy density and superior safety [4]. Composite polymer electrolytes (CPEs), such as poly(ethylene oxide) (PEO), are the most promising candidate material for commercial SSLIB [5, 6]. However, the low ionic conductivity that resulted from high crystallinity still cannot be satisfied for application. To solve this problem, inorganic particles

Fusheng Pan

fspan@tju.edu.cn

$\triangle$ Jie Sun

jies@tju.edu.cn

1 Key Laboratory for Green Chemical Technology of Ministry of Education, School of Chemical Engineering and Technology, Tianjin University, Tianjin 300072, China

2 Sinopec Research Institute of Petroleum Processing, Beijing 100728, China

3 Chemistry and Chemical Engineering Guangdong Laboratory, Shantou 515031, China such as oxides and sulfides were widely used as fillers to decrease the crystallinity of PEO or construct extra Li-ion conductive pathways $[7,8]$. Traditional efficient fillers have some shortcomings: (1) oxides usually need a high-temperature treatment, such as $\mathrm{Li}_{7} \mathrm{La}_{3} \mathrm{Zr}_{2} \mathrm{O}_{12}\left(>900{ }^{\circ} \mathrm{C}\right)$ [9]; (2) most oxides and sulfides are sensitive to water and air [10,11]; (3) the high weight content of fillers hinders the improvement in the overall battery's energy density. Therefore, great efforts in finding better fillers are needed for practical applications.

Covalent organic frameworks (COFs) are a new kind of porous materials with advantages such as highly adjustable structures, light mass, high specific surface area, and unique one-dimensional channel structures $[12,13]$. Although these features are suitable for use as fillers, COFs are rarely applied in CPEs due to their poor ionic conductivity [14-16]. To enhance the intrinsic Li-ion conductivity of COFs, this study prepared a lithiated $\mathrm{COF}$ (named $\mathrm{TpPa}-\mathrm{SO}_{3} \mathrm{Li}$ ) by a mild chemical lithiation strategy. The obtained $\mathrm{TpPa}_{-} \mathrm{SO}_{3} \mathrm{Li}$ was selected as the active filler in the CPE for SSLIB. Compared with other fillers without Li-ion conductivity, the $\mathrm{TpPa}-\mathrm{SO}_{3} \mathrm{Li}$ provides a rapid $\mathrm{Li}$-ion transfer via the $-\mathrm{SO}_{3} \mathrm{Li}$ groups as Li-ion conducting sites in the nanochannels, which work as the expressway between the PEO chains, leading to enhanced Li-ion conductivity. Moreover, the extra advantages of high chemical stability and low density provide the potential for practical application. Results show that the 
$\mathrm{TpPa}-\mathrm{SO}_{3} \mathrm{Li}$ serves as promising filler in $\mathrm{CPE}$ and enhances the electrochemical performances of $\mathrm{LiFePO}_{4} \| \mathrm{Li}$ SSLIB.

\section{Experiment Section}

$\mathrm{TpPa}-\mathrm{SO}_{3} \mathrm{Li}$ was prepared by solvothermal and chemical lithiation methods [13]. TpPa-SO $\mathrm{SO}_{3} \mathrm{Li}, \mathrm{PEO}$ (molecular weight $M_{\mathrm{w}} \approx 6 \times 10^{5}$ ), and $\mathrm{LiClO}_{4}$ were dissolved in anhydrous acetonitrile with a certain weight ratio of EO: $\mathrm{Li}=18: 1$. The homogenized suspension was cast into a polytetrafluoroethylene mold and dried at room temperature for $24 \mathrm{~h}$. After further drying at $55^{\circ} \mathrm{C}$ for another $12 \mathrm{~h}$ under vacuum, the $\mathrm{CPE}$ membrane (named (PEO) ${ }_{18} \mathrm{LiClO}_{4} /$ $\mathrm{TpPa}-\mathrm{SO}_{3} \mathrm{Li}(x), x$ is the mass fraction of $\left.\mathrm{TpPa}-\mathrm{SO}_{3} \mathrm{Li}\right)$ was obtained. The $\mathrm{CPE}$ without $\mathrm{TpPa}-\mathrm{SO}_{3} \mathrm{Li}$ was denoted as $(\mathrm{PEO})_{18} \mathrm{LiClO}_{4}$.

\section{Results and Discussions}

Figure 1a shows the chemical structure of $\mathrm{TpPa}-\mathrm{SO}_{3} \mathrm{H}$, which was synthesized by the Schiff base condensation reaction of 2,4,6-trihydroxybenzene-1,3,5-tricarbaldehyde (Tp) and 2,5-diaminobenzenesulfonic acid $\left(\mathrm{Pa}_{-} \mathrm{SO}_{3} \mathrm{H}\right)$. The enol-imine form converted to keto-enamine form after condensation. It was lithiated by Lewis acid-base reaction using lithium acetate. As shown in Fig. 1b, the Fourier transform infrared (FT-IR) peaks of $\mathrm{TpPa}-\mathrm{SO}_{3} \mathrm{H}$ at 1240,1575 , and $3400 \mathrm{~cm}^{-1}$ represent the $\mathrm{C}-\mathrm{N}, \mathrm{C}=\mathrm{C}$, and enamine $\mathrm{N}-\mathrm{H}$ bonds, respectively. The peak at $3200 \mathrm{~cm}^{-1}$, which corresponds to $\mathrm{O}-\mathrm{H}$ bonds in sulfonates, is found in $\mathrm{TpPa}-\mathrm{SO}_{3} \mathrm{H}$. After being lithiated, this peak significantly weakened, indicating that the $\mathrm{H}$ atoms in the $-\mathrm{OH}$ groups are replaced by $\mathrm{Li}$ atoms. Meanwhile, the $\mathrm{O}-\mathrm{Li}$ bonds form and show a characteristic peak at $1750 \mathrm{~cm}^{-1}$, which overlaps with the characteristic peak of $\mathrm{C}=\mathrm{O}$ bonds. $\mathrm{X}$-ray photoelectron spectroscopy (XPS) spectra (Fig. 1c and Fig. S1) also confirm the lithium substitution. Due to the splitting of the spin-orbit, double peaks appear in the S $2 p$ spectrum and shift to higher binding energy after being lithiated. It confirms that the environment of the $\mathrm{S}$ atom has changed, which is attributed to the substitution of $\mathrm{H}$ atoms in the sulfonates by $\mathrm{Li}$ atoms [17].

Scanning electron microscopy (SEM) images show that the $\mathrm{TpPa}-\mathrm{SO}_{3} \mathrm{H}$ and $\mathrm{TpPa}-\mathrm{SO}_{3} \mathrm{Li}$ have similar stacked particle structures (Fig. 1d, e). These particles have an average diameter of less than $100 \mathrm{~nm}$ and are formed by stacking porous nanosheets. The X-ray diffraction (XRD) pattern of $\mathrm{TpPa}-\mathrm{SO}_{3} \mathrm{H}$ (Fig. 1f) shows the characteristic peaks at $2 \theta=4.6^{\circ}$ and $26.2^{\circ}$ that correspond to (100) and (001) planes, respectively. This confirms the ordered pores with a pore size of $1.88 \mathrm{~nm}$ and an interlayer distance of $3.4 \AA$. This indicates that the lithiation process has basically no effect on the layered structure and morphology. The crystalline structure of $\mathrm{TpPa}-\mathrm{SO}_{3} \mathrm{Li}$ can be verified by the transmission (a)
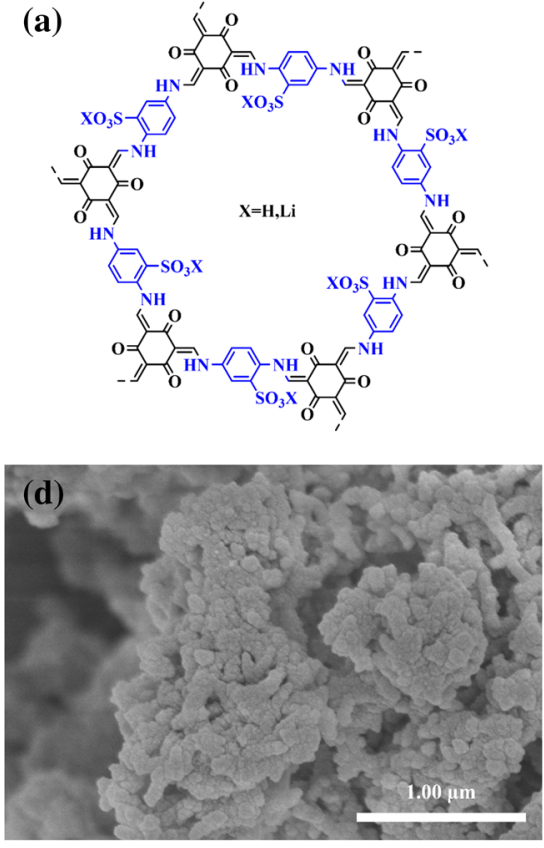

(b)
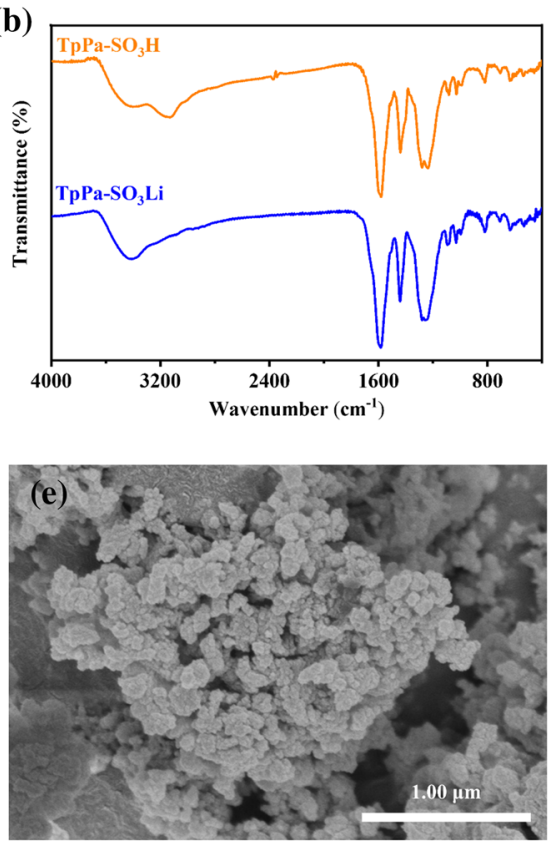

(c)
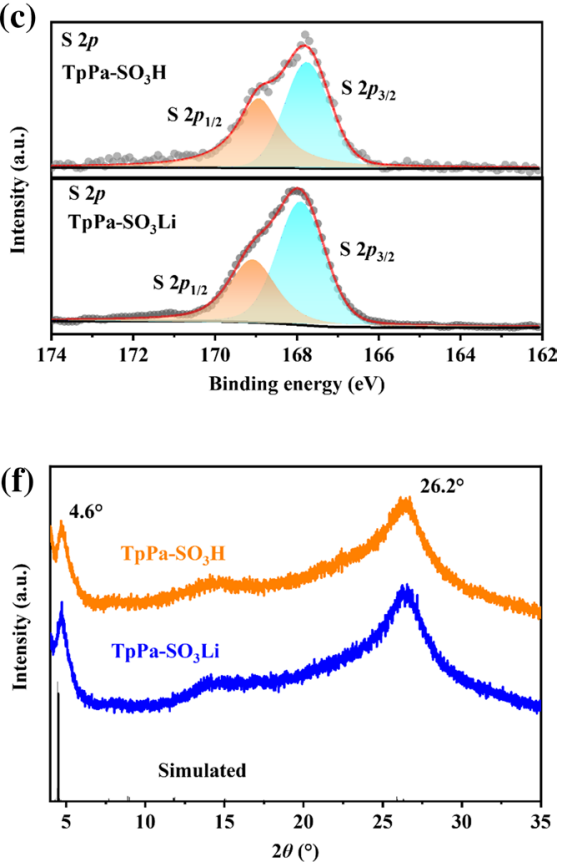

Fig. 1 a Chemical structure of $\mathrm{TpPa}-\mathrm{SO}_{3} \mathrm{X}(\mathrm{X}=\mathrm{H}, \mathrm{Li})$. b FT-IR spectra of $\mathrm{TpPa}-\mathrm{SO}_{3} \mathrm{H}$ and $\mathrm{TpPa}-\mathrm{SO}_{3} \mathrm{Li}$. c XPS spectra of $\mathrm{S} 2 \mathrm{p}$ in TpPa-SO $\mathrm{X}_{3} \mathrm{H}$ and TpPa-SO $\mathrm{SL}_{3} \mathrm{Li}$. SEM images of (d) $\mathrm{TpPa}-\mathrm{SO}_{3} \mathrm{H}$ and (e) $\mathrm{TpPa}-\mathrm{SO}_{3} \mathrm{Li}$. f XRD patterns of TpPa-SO $\mathrm{S}_{3} \mathrm{H}$ and $\mathrm{TpPa}-\mathrm{SO}_{3} \mathrm{Li}$ 
electron microscopy (TEM) image (Fig. S2) as well. The Li content obtained by the inductively coupled plasma optical emission spectrometer is about $1.53 \mathrm{wt} . \%$, which is a little lower than the theoretical value of $2.33 \mathrm{wt} . \%$.

$\mathrm{TpPa}-\mathrm{SO}_{3} \mathrm{Li}$ can be uniformly dispersed in the casting solution without sedimentation (Fig. S3). As shown in Fig. 2a and Fig. S4, the CPEs are flexible with a thickness of $\sim 50 \mu \mathrm{m}$ and have a uniform surface without visible defects or pellets (Fig. 2b, c). In addition, there is no obvious difference in the surface morphology of CPEs with or without $\mathrm{TpPa}-\mathrm{SO}_{3} \mathrm{Li}$. The uniform dispersion of $\mathrm{TpPa}-\mathrm{SO}_{3} \mathrm{Li}$ in $\mathrm{PEO}$ can be demonstrated by the cross-sectional energydispersive spectrometer (EDS) mapping of S (Fig. 2d). The XRD characterization was performed to study the crystallinity of CPEs in Fig. 2e, indicating that the introduction of $\mathrm{TpPa}-\mathrm{SO}_{3} \mathrm{Li}$ with various ratios has no effect on the crystallinity of CPEs either [5]. After adding 0.75 wt.\% TpPa$\mathrm{SO}_{3} \mathrm{Li}$, the melting enthalpy of CPEs changes from $88.03 \mathrm{~J} / \mathrm{g}$ to $91.88 \mathrm{~J} / \mathrm{g}$. (Fig. 2f). Correspondingly, the crystallinity of CPEs increased from 41.19 to $42.99 \%$, which suggests that the crystallinity of CPEs is hardly affected.

To study the influence of $\mathrm{TpPa}-\mathrm{SO}_{3} \mathrm{Li}$ on the ionic conductivity, this work assembled SSICPEISS cells (SS represents stainless steel) and performed electrochemical impedance spectroscopy (EIS). Figure 3a shows the typical spectra of $(\mathrm{PEO})_{18} \mathrm{LiClO}_{4} / \mathrm{TpPa}-\mathrm{SO}_{3} \mathrm{Li}(0.75)$ at different temperatures. The resistance decreases rapidly with the increase in temperature. At $50{ }^{\circ} \mathrm{C}$ and above, the semicircle disappears, indicating a decreased interface resistance because of the improved interface interaction. As shown in Fig. 3b, with the increase in the $\mathrm{TpPa}_{\mathrm{SO}} \mathrm{Si}$ content, the ionic conductivity shows a trend of initially rising and then falling with inflection points at $0.75 \mathrm{wt} . \% \mathrm{TpPa}-\mathrm{SO}_{3} \mathrm{Li}$ content. Taking the curve at $60{ }^{\circ} \mathrm{C}$ as an example, the ionic conductivity ranges from $1.62 \times 10^{-4}$ to $3.01 \times 10^{-4} \mathrm{~S} / \mathrm{cm}$ as the filling amount increases from 0 to $0.75 \mathrm{wt} . \%$. When the content is further increased and exceeds the threshold, the conductivity drops rapidly to even lower than that of $(\mathrm{PEO})_{18} \mathrm{LiClO}_{4}$. This phenomenon can be explained by the percolation behavior. It is attributed to aggregation, phase separation, and bubbles caused by excess $\mathrm{TpPa}-\mathrm{SO}_{3} \mathrm{Li}$, which goes against ion conduction. Moreover, due to the low density and high specific surface area of $\mathrm{TpPa}-\mathrm{SO}_{3} \mathrm{Li}$, the ionic conductivity can be improved at a very low content, and the threshold of the percolation behavior is only about $0.75 \mathrm{wt} . \%$.

To study the effect of the lithiation sites, $(\mathrm{PEO}){ }_{18} \mathrm{LiClO}_{4} / \mathrm{TpPa}-\mathrm{SO}_{3} \mathrm{H}(0.75)$ was prepared with the same method, and its ionic conductivity was tested at different temperatures. As shown in Fig. 3c, the ionic conductivity of $(\mathrm{PEO})_{18} \mathrm{LiClO}_{4} / \mathrm{TpPa}-\mathrm{SO}_{3} \mathrm{H}(0.75)$ is significantly lower than that of $(\mathrm{PEO})_{18} \mathrm{LiClO}_{4}$. Since $\mathrm{TpPa}-\mathrm{SO}_{3} \mathrm{H}$ does not have Li-ion conductivity, its uniform dispersion in CPEs may form micro-domains that are not conducive to the $\mathrm{Li}$-ion. In addition, the $\mathrm{H}$-ions that dissociated from the sulfonates hinder the $\mathrm{Li}$-ions from entering the nanochannels of $\mathrm{TpPa}-\mathrm{SO}_{3} \mathrm{H}$ by steric hindrance and Coulomb (a)
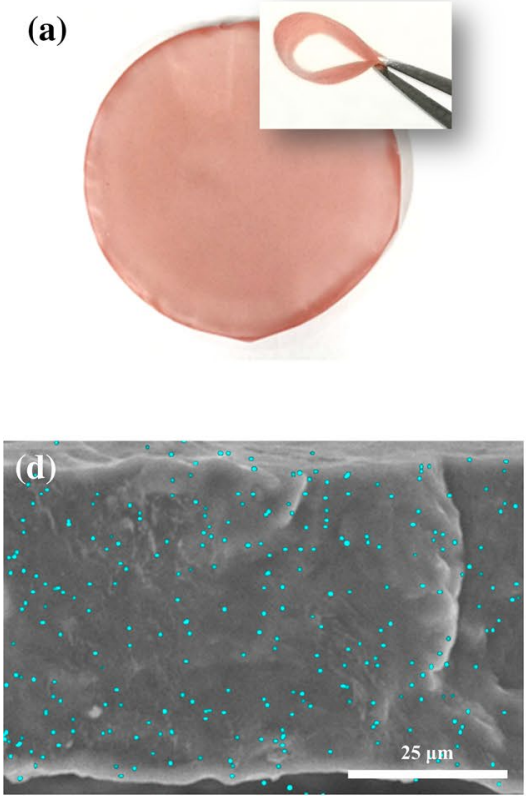
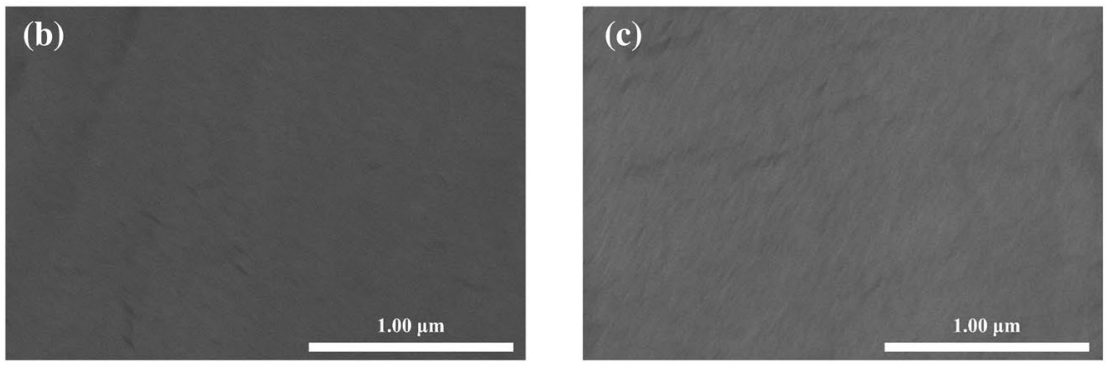

(e)

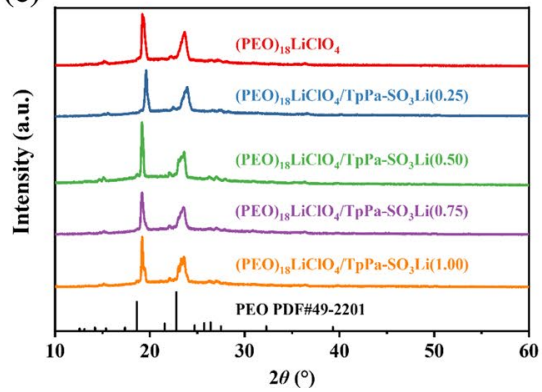

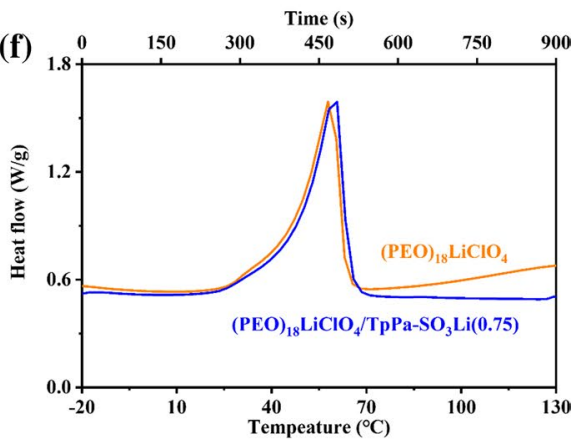

Fig. 2 a Digital photographs of $(\mathrm{PEO})_{18} \mathrm{LiClO}_{4} / \mathrm{TpPa}-\mathrm{SO}_{3} \mathrm{Li}(0.75)$. SEM images of (b) $(\mathrm{PEO})_{18} \mathrm{LiClO}_{4}$ and (c) $(\mathrm{PEO})_{18} \mathrm{LiClO}_{4} / \mathrm{TpPa}-$ $\mathrm{SO}_{3} \mathrm{Li}(0.75)$. d Cross-sectional SEM image and S EDS mapping of
(PEO) ${ }_{18} \mathrm{LiClO}_{4} / \mathrm{TpPa}-\mathrm{SO}_{3} \mathrm{Li}(0.75)$. e XRD patterns of the CPEs. $\mathbf{f}$ DSC traces of $(\mathrm{PEO})_{18} \mathrm{LiClO}_{4}$ and $(\mathrm{PEO})_{18} \mathrm{LiClO}_{4} / \mathrm{TpPa}-\mathrm{SO}_{3} \mathrm{Li}(0.75)$ 
(a)

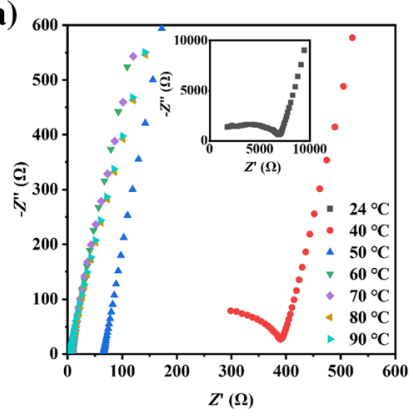

(d)

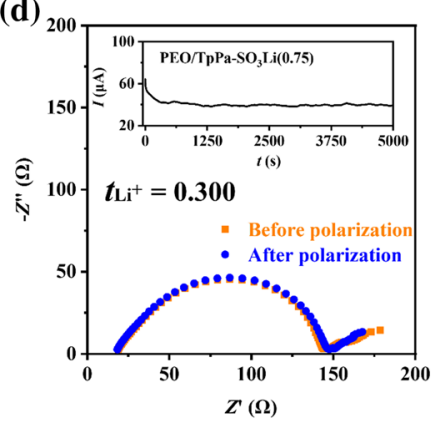

(b)

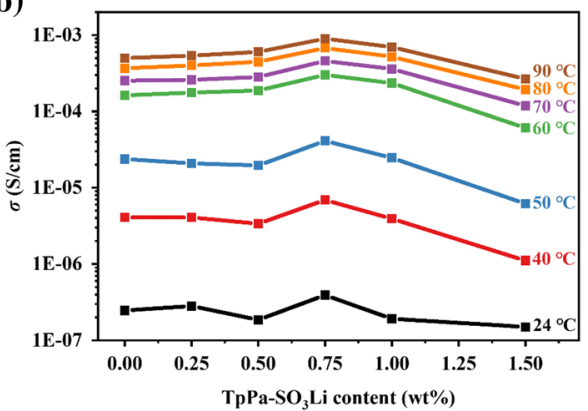

(e)

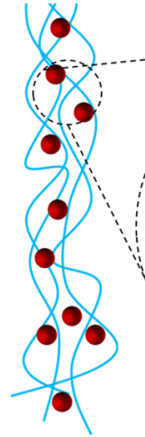

(c)

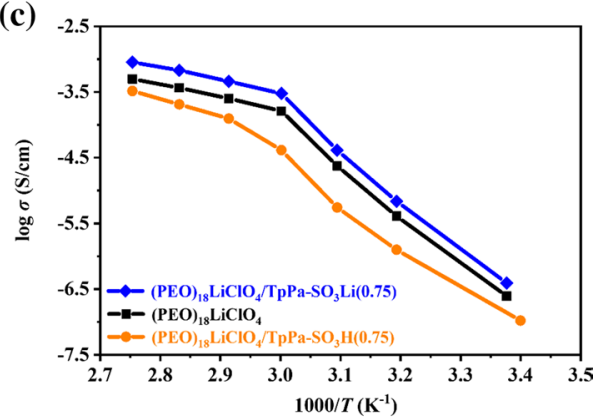

Fig. 3 a EIS spectra of $(\mathrm{PEO})_{18} \mathrm{LiClO}_{4} / \mathrm{TpPa}-\mathrm{SO}_{3} \mathrm{Li}(0.75)$ at different temperatures. b Ionic conductivity of CPEs at different temperatures and $\mathrm{TpPa}-\mathrm{SO}_{3} \mathrm{Li}$ contents. c Arrhenius plot for the ionic conductivity of CPEs with $\mathrm{TpPa}-\mathrm{SO}_{3} \mathrm{H}$ or $\mathrm{TpPa}-\mathrm{SO}_{3} \mathrm{Li}$. d EIS spectra of
$(\mathrm{PEO})_{18} \mathrm{LiClO}_{4} / \mathrm{TpPa}-\mathrm{SO}_{3} \mathrm{Li}(0.75)$ before and after polarization (inset shows the corresponding $I-t$ curve). e Schematic illustration of $\mathrm{Li}$-ion conductive mechanism of $(\mathrm{PEO})_{18} \mathrm{LiClO}_{4} / \mathrm{TpPa}-\mathrm{SO}_{3} \mathrm{Li}(0.75)$ interaction, which further increases the Li-ion diffusion energy barrier. The chemical lithiation method can replace $\mathrm{H}$-ions with Li-ions, introduce evenly distributed Li-ion jumping conduction sites, and construct low-resistance transmission channels.

In addition to the high ionic conductivity, sulfonates in $\mathrm{TpPa}-\mathrm{SO}_{3} \mathrm{Li}$ serve as single Li-ion conduction sites, which is beneficial to increase the $\mathrm{Li}$-ion transference number $\left(t_{\mathrm{Li}^{+}}\right)$[13]. Chronoamperometry and EIS were carried out at $60{ }^{\circ} \mathrm{C}$ to measure the $t_{\mathrm{Li}^{+}}$using LilCPElLi cells. As shown in Fig. 3d and Fig. S5, (PEO) ${ }_{18} \mathrm{LiClO}_{4} / \mathrm{TpPa}-\mathrm{SO}_{3} \mathrm{Li}(0.75)$ delivers a $t_{\mathrm{Li}^{+}}$of 0.300 , while $(\mathrm{PEO})_{18} \mathrm{LiClO}_{4}$ shows a $t_{\mathrm{Li}^{+}}$ of 0.258 .

The improvements in the ionic conductivity and $t_{\mathrm{Li}^{+}}$benefit from the structure and composition of $\mathrm{TpPa}-\mathrm{SO}_{3} \mathrm{Li}$. As shown in Fig. 3e, the unique one-dimensional channel structure provides rapid $\mathrm{Li}$-ion transfer and shortens the transfer distance. Meanwhile, lithiation sites in the channels significantly reduce the $\mathrm{Li}$-ion diffusion barrier.

The linear sweep voltammetry (LSV) measurement was performed at $60{ }^{\circ} \mathrm{C}$ to study the electrochemical stability window of the CPEs (Fig. 4a). The result shows that $(\mathrm{PEO})_{18} \mathrm{LiClO}_{4}$ and $(\mathrm{PEO})_{18} \mathrm{LiClO}_{4} / \mathrm{TpPa}-\mathrm{SO}_{3} \mathrm{Li}(0.75)$ are electrochemically stable at the voltage range of $1.0-4.5 \mathrm{~V}$. Within the operating voltage range of $\mathrm{LiFePO}_{4}$, both PEO and $\mathrm{TpPa}-\mathrm{SO}_{3} \mathrm{Li}$ can be kept stable.
Li symmetric cells were characterized by charge/discharge measurements at $60{ }^{\circ} \mathrm{C}, 0.1 \mathrm{~mA} / \mathrm{cm}^{2}$, and $0.1 \mathrm{~mA} \cdot \mathrm{h} /$ $\mathrm{cm}^{2}$ to study the interfacial stability. As shown in Fig. S6, the overpotential of $\mathrm{Lil}(\mathrm{PEO})_{18} \mathrm{LiClO}_{4} / \mathrm{TpPa}-\mathrm{SO} \mathrm{O}_{3} \mathrm{Li}(0.75) \mid \mathrm{Li}$ is much smaller than that of $\mathrm{Lil}(\mathrm{PEO})_{18} \mathrm{LiClO}_{4} \mid \mathrm{Li}$. Moreover, $\mathrm{Lil}(\mathrm{PEO})_{18} \mathrm{LiClO}_{4} \mid \mathrm{Li}$ is short-circuited after cycling for $80 \mathrm{~h}$, which signifies that $(\mathrm{PEO})_{18} \mathrm{LiClO}_{4} / \mathrm{TpPa}-\mathrm{SO}_{3} \mathrm{Li}(0.75)$ has a more stable interface with lithium than $(\mathrm{PEO}){ }_{18} \mathrm{LiClO}_{4}$.

To explore the practical application of the CPEs, this work assembled $\mathrm{LiFePO}_{4} \mid \mathrm{CPEILi}$ cells and measured their electrochemical performance at $60^{\circ} \mathrm{C}$ and $0.5 \mathrm{C}$ with activation at $0.1 \mathrm{C}$ for five cycles. As shown in Fig. $4 \mathrm{~b}$, the polarization voltage of $\mathrm{LiFePO}_{4}\left|(\mathrm{PEO})_{18} \mathrm{LiClO}_{4}\right| \mathrm{Li}$ significantly increases with the cycle process, while $\mathrm{LiFePO}_{4} \mid(\mathrm{PEO})_{18} \mathrm{LiClO}_{4} /$ $\mathrm{TpPa}-\mathrm{SO}_{3} \mathrm{Li}(0.75) \mid \mathrm{Li}$ exhibits a stable polarization voltage of $0.11 \mathrm{~V}$ (Fig. 4c). This proves that it has the potential to be applied in SSLIB.

As shown in Fig. 4d, $\mathrm{LiFePO}_{4}\left|(\mathrm{PEO})_{18} \mathrm{LiClO}_{4}\right| \mathrm{Li}$ delivers initial and stable discharge capacities of 151.2 and $118 \mathrm{~mA} \cdot \mathrm{h} / \mathrm{g}$ in the first 250 cycles, respectively. On the other hand, $\mathrm{LiFePO}_{4}(\mathrm{PEO}){ }_{18} \mathrm{LiClO}_{4} /$ $\mathrm{TpPa}-\mathrm{SO}_{3} \mathrm{Li}(0.75) \mid \mathrm{Li}$ shows initial and stable discharge capacities of 154.7 and $125 \mathrm{~mA} \cdot \mathrm{h} / \mathrm{g}$, respectively. The unstable Coulombic efficiency may be due to the side reaction caused by the trace solvent in the CPEs. The Coulombic efficiency of $\mathrm{LiFePO}_{4}\left|(\mathrm{PEO})_{18} \mathrm{LiClO}_{4}\right| \mathrm{Li}$ 
(a)

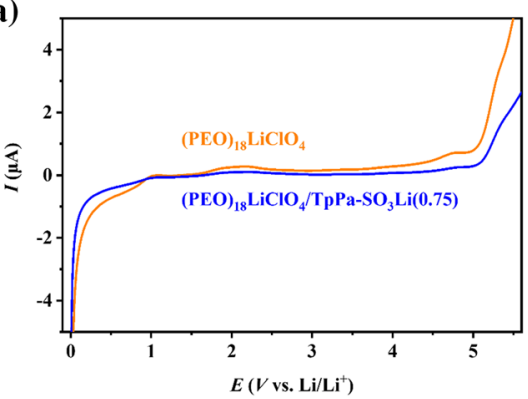

(d)

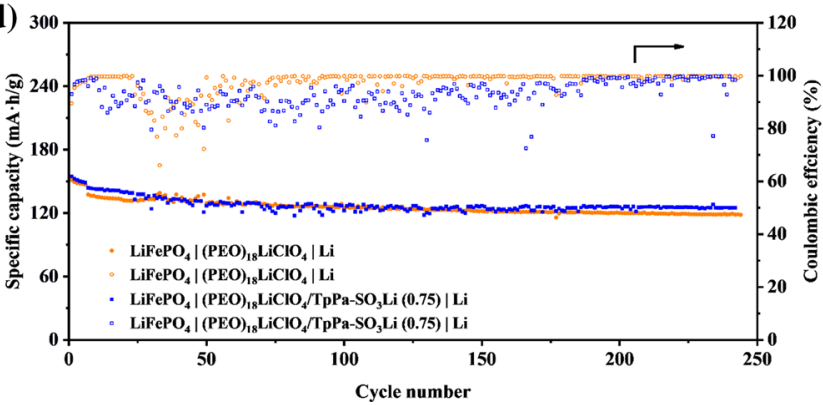

Fig. 4 a LSV profiles of $(\mathrm{PEO})_{18} \mathrm{LiClO}_{4}$ and $(\mathrm{PEO})_{18} \mathrm{LiClO}_{4} /$ $\mathrm{TpPa}-\mathrm{SO}_{3} \mathrm{Li}(0.75)$. b Charge/discharge curves of $\mathrm{LiFePO}_{4}\left|(\mathrm{PEO})_{18} \mathrm{LiClO}_{4}\right| \mathrm{Li}$. c Charge/discharge curves of $\mathrm{LiFePO}_{4}\left|(\mathrm{PEO})_{18} \mathrm{LiClO}_{4} / \mathrm{TpPa}-\mathrm{SO}_{3} \mathrm{Li}(0.75)\right| \mathrm{Li} . \quad$ d Cycling per-

was basically stable after 75 cycles. The unlithiated sulfonate in $\mathrm{TpPa}_{-} \mathrm{SO}_{3} \mathrm{Li}$ will be electrochemically lithiated, leading to a fluctuating Coulombic efficiency of $\mathrm{LiFePO}_{4}(\mathrm{PEO})_{18} \mathrm{LiClO}_{4} / \mathrm{TpPa}-\mathrm{SO}_{3} \mathrm{Li}(0.75) \mid \mathrm{Li}$. To test the stability of $\mathrm{LiFePO}_{4} \mid \mathrm{CPEI} / \mathrm{Li}$ cells to temperature, the cells were cooled to room temperature for $24 \mathrm{~h}$ after 250 cycles and then tested at $60{ }^{\circ} \mathrm{C}$ and $0.5 \mathrm{C}$ again (Fig. S7). The stable discharge capacities of $\mathrm{LiFePO}_{4}\left|(\mathrm{PEO})_{18} \mathrm{LiClO}_{4}\right| \mathrm{Li}$ and $\mathrm{LiFePO}_{4}\left|(\mathrm{PEO})_{18} \mathrm{LiClO}_{4} / \mathrm{TpPa}-\mathrm{SO}_{3} \mathrm{Li}(0.75)\right| \mathrm{Li}$ decayed to 100 and $113 \mathrm{~mA} \cdot \mathrm{h} / \mathrm{g}$, respectively. The corresponding capacity retention rates before and after cooling were $84.7 \%$ and $90.4 \%$, respectively, indicating that $\mathrm{LiFePO}_{4}\left|(\mathrm{PEO})_{18} \mathrm{LiClO}_{4} / \mathrm{TpPa}-\mathrm{SO}_{3} \mathrm{Li}(0.75)\right| \mathrm{Li}$ was more stable to temperature.

EIS spectra at the reduction state were tested to study the interfacial stability. As shown in Fig. 4e, $\mathrm{LiFePO}_{4}\left|(\mathrm{PEO})_{18} \mathrm{LiClO}_{4}\right| \mathrm{Li}$ shows two overlapped semicircles in the middle- and high-frequency range. Moreover, the impedance increases rapidly during cycling, which means a serious interface reaction between $(\mathrm{PEO})_{18} \mathrm{LiClO}_{4}$ and electrodes. After three cycles, $\mathrm{LiFePO}_{4}\left|(\mathrm{PEO})_{18} \mathrm{LiClO}_{4} / \mathrm{TpPa}-\mathrm{SO}_{3} \mathrm{Li}(0.75)\right| \mathrm{Li}$ shows only one semicircle (Fig. 4f), and the corresponding impedance is smaller than that of the initial state. Therefore, the addition of $\mathrm{TpPa}-\mathrm{SO}_{3} \mathrm{Li}$ effectively improved the interface stability between the CPE and electrodes.
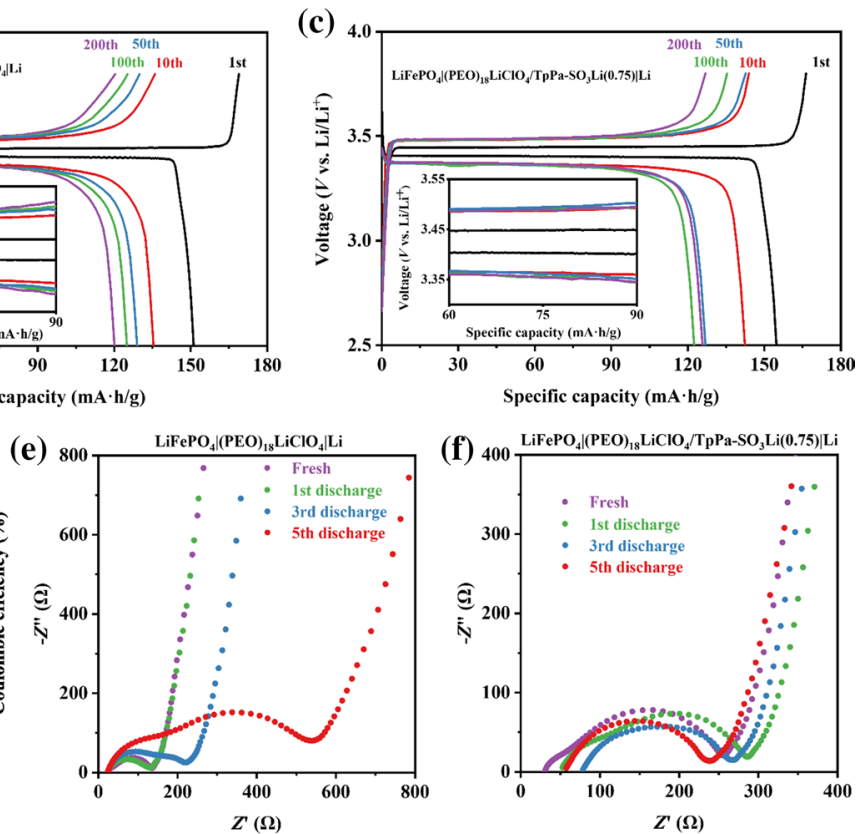

formance of $\mathrm{LiFePO}_{4} \mid \mathrm{CPE} / \mathrm{Li}$ cells at $0.5 \mathrm{C}$ and $60{ }^{\circ} \mathrm{C}$. e EIS spectra of $\mathrm{LiFePO}_{4}\left|(\mathrm{PEO})_{18} \mathrm{LiClO}_{4}\right| \mathrm{Li}$. f EIS spectra of $\mathrm{LiFePO}_{4}\left|(\mathrm{PEO})_{18} \mathrm{LiClO}_{4} / \mathrm{TpPa}-\mathrm{SO}_{3} \mathrm{Li}(0.75)\right| \mathrm{Li}$

\section{Conclusions}

The $\mathrm{TpPa}-\mathrm{SO}_{3} \mathrm{Li}$ was prepared via a mild chemical lithiation strategy and applied as active filler in the PEO-based CPE. The $-\mathrm{SO}_{3} \mathrm{Li}$ groups in $\mathrm{TpPa}-\mathrm{SO}_{3} \mathrm{Li}$ work as $\mathrm{Li}$-ion conducting sites in the nanochannels, providing an expressway between the PEO chains. Therefore, high ionic conductivity of $3.01 \times 10^{-4}$ $\mathrm{S} / \mathrm{cm}$ was obtained at $60^{\circ} \mathrm{C}$. When the CPE with only 0.75 wt. $\% \mathrm{TpPa}-\mathrm{SO}_{3} \mathrm{Li}$ was assembled in the SSLIB, it delivered a reversible capacity of $125 \mathrm{~mA} \cdot \mathrm{h} / \mathrm{g}$ after 250 cycles at 0.5 $\mathrm{C}$ and $60^{\circ} \mathrm{C}$. This strategy provides a convenient method to prepare $\mathrm{Li}$-ion conducting COFs and provides a new path for lightweight CPEs.

Supplementary Information The online version contains supplementary material available at https://doi.org/10.1007/s12209-021-00300-z.

Acknowledgements This work was supported by the State Key Laboratory of Catalytic Materials and Reaction Engineering (RIPP, SINOPEC), the National Natural Science Foundation of China (Nos. 21878216, 22005215), Hebei Province Innovation Ability Promotion Project (No. 20312201D), and the National Key Research and Development Program of China (No. 2019YFE0118800). 


\section{Declarations}

Conflict of interests The authors declare that there is no conflict of interest.

Open Access This article is licensed under a Creative Commons Attribution 4.0 International License, which permits use, sharing, adaptation, distribution and reproduction in any medium or format, as long as you give appropriate credit to the original author(s) and the source, provide a link to the Creative Commons licence, and indicate if changes were made. The images or other third party material in this article are included in the article's Creative Commons licence, unless indicated otherwise in a credit line to the material. If material is not included in the article's Creative Commons licence and your intended use is not permitted by statutory regulation or exceeds the permitted use, you will need to obtain permission directly from the copyright holder. To view a copy of this licence, visit http://creativecommons.org/licenses/by/4.0/.

\section{References}

1. Li C, Zhang X, Lv Z et al (2021) Scalable combustion synthesis of graphene-welded activated carbon for high-performance supercapacitors. Chem Eng J. 414:128781

2. Yi S, Wang L, Zhang $X$ et al (2021) Cationic intermediates assisted self-assembly two-dimensional $\mathrm{Ti}_{3} \mathrm{C}_{2} \mathrm{~T}_{x} / \mathrm{rGO}$ hybrid nanoflakes for advanced lithium-ion capacitors. Sci Bull 66(9):914-924

3. Yu Z, Zhang JJ, Wang C et al (2020) Flame-retardant concentrated electrolyte enabling a LiF-rich solid electrolyte interface to improve cycle performance of wide-temperature lithium-sulfur batteries. J Energy Chem 51:154-160

4. Zhou Q, Ma J, Dong SM et al (2019) Intermolecular chemistry in solid polymer electrolytes for high-energy-density lithium batteries. Adv Mater 31(50):1902029

5. Ito $\mathrm{Y}$, Kanehori K, Miyauchi K et al (1987) Ionic conductivity of electrolytes formed from $\mathrm{PEO}-\mathrm{LiCF}_{3} \mathrm{SO}_{3}$ complex low molecular weight poly(ethylene glycol). J Mater Sci 22(5):1845-1849

6. Zhu XQ, Wang K, Xu YN et al (2021) Strategies to boost ionic conductivity and interface compatibility of inorganic-organic solid composite electrolytes. Energy Storage Mater 36:291-308

7. Boaretto N, Meabe L, Martinez-Ibañez M et al (2020) Reviewpolymer electrolytes for rechargeable batteries: from nanocomposite to nanohybrid. J Electrochem Soc 167(7):070524

8. Wang JJ, Yuan B, Pan FS et al (2020) Nano-silica-decorated poly (m-phenylene isophthalamide) separator with enhanced mechanical and electrolyte wetting properties for lithium-ion batteries. Trans Tianjin Univ 26(4):256-264

9. Murugan R, Thangadurai V, Weppner W (2007) Fast lithium ion conduction in garnet-type $\mathrm{Li}_{7} \mathrm{La}_{3} \mathrm{Zr}_{2} \mathrm{O}_{12}$. Angew Chem Int Ed 46(41):7778-7781

10. Hakari T, Nagao M, Hayashi A et al (2015) All-solid-state lithium batteries with $\mathrm{Li}_{3} \mathrm{PS}_{4}$ glass as active material. J Power Sources 293:721-725

11. Xu XY, Li YY, Cheng J et al (2020) Composite solid electrolyte of $\mathrm{Na}_{3} \mathrm{PS}_{4}$-PEO for all-solid-state $\mathrm{SnS}_{2} / \mathrm{Na}$ batteries with excellent interfacial compatibility between electrolyte and Na metal. J Energy Chem 41:73-78

12. Cao Y, Liu C, Wang MD et al (2020) Lithiation of covalent organic framework nanosheets facilitating lithium-ion transport in lithium-sulfur batteries. Energy Storage Mater 29:207-215

13. Jeong K, Park S, Jung GY et al (2019) Solvent-free, single lithium-ion conducting covalent organic frameworks. J Am Chem Soc 141(14):5880-5885

14. Sun W, Zhang J, Xie M et al (2020) Ultrathin aramid/COF heterolayered membrane for solid-state Li-metal batteries. Nano Lett 20(11):8120-8126

15. Zhang G, Hong YL, Nishiyama Y et al (2019) Accumulation of glassy poly(ethylene oxide) anchored in a covalent organic framework as a solid-state $\mathrm{Li}^{+}$electrolyte. J Am Chem Soc 141(3):1227-1234

16. Guo ZB, Zhang YY, Dong Y et al (2019) Fast ion transport pathway provided by polyethylene glycol confined in covalent organic frameworks. J Am Chem Soc 141(5):1923-1927

17. Wang SH, Yue J, Dong W et al (2019) Tuning wettability of molten lithium via a chemical strategy for lithium metal anodes. Nat Commun 10(1):4930

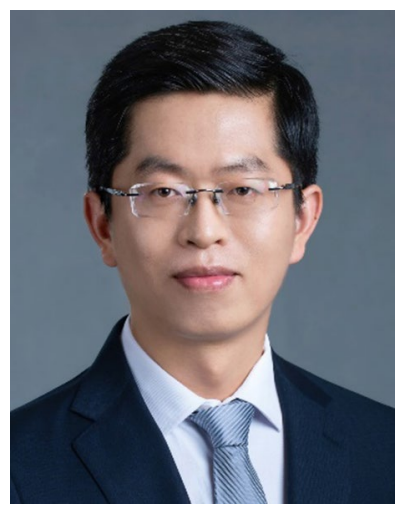

Fusheng Pan Fusheng Pan is an Associate Professor at School of Chemical Engineering and Technology of Tianjin University. He received his $\mathrm{Ph} . \mathrm{D}$. degree in School of Chemical Engineering and Technology from Tianjin University in 2009. He then worked as a postdoctoral fellow at Tsinghua University from 2009 to 2011 . He was a visiting scholar of Georgia Institute of Technology in 2015. He is the recipient of Backbone Peiyang Scholar Youth Teacher of Tianjin University. His current research interests focus on the design and fabrication of membranes for liquid separation, lithium-ion battery and ECMO. To date, he has coauthored over 110 peer-reviewed scientific papers, and his h-index is 35 .

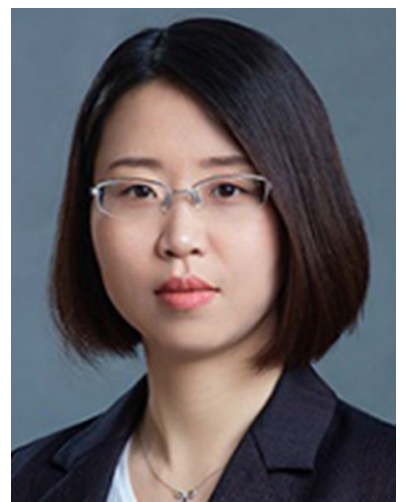

Jie Sun Jie Sun is a professor at the Tianjin University, China. She earned her Ph.D. from the Beijing University of Chemical Technology and then worked as a postdoctoral at the Stanford University. Her current research interests focus on the development of multifunctional nanomaterials for energy conversion and storage, including Li-ion, $\mathrm{Na}$ ion, K-ion batteries, lithium-sulfur batteries, as well as electrocatalysis. 